\begin{tabular}{|c|l|}
\hline Title & $\begin{array}{l}\text { PHOTOEMISSION OF ELECTRONS INTO ELECTROLYTES FROM SOLID METALS WITH POOR } \\
\text { HYDROGEN ADSORPTION PROPERTIES }\end{array}$ \\
\hline Author(s) & ROTENBERG, Z. A.; PRISHCHEPA, Yu. A.; PLESK OV, Y u. V. \\
\hline Citation & JOURNAL OF THE RESEARCH INSTITUTE FOR CA TALY SIS HOKKA IDO UNIVERSITY, 22(2), 125-125 \\
\hline Issue Date & 1975-08 \\
\hline Doc URL & http://hdl.handle.net/2115/24975 \\
\hline Type & bulletin (article) \\
\hline File Information & 22(2)_P125.pdf \\
\hline
\end{tabular}

Instructions for use 
J. Res. Inst. Catalysis, Hokkaido Univ., Vol. 22 No. 2, p. 125 (1974)

(Note)

\title{
PHOTOEMISSION OF ELECTRONS INTO ELECTROLYTES FROM SOLID METALS WITH POOR HYDROGEN ADSORPTION PROPERTIES*)
}

By

\author{
Z. A. Rotenberg, Yu. A. Prishchepa \\ and Yu. V. Pleskov**) \\ (Received October 5, 1974)
}

\begin{abstract}
Summary
Investigation of photoelectron emission from lead, cadminm, indium and bismuth into aqueous solutions has supported basic relationships obtained earlier for mercury electrode, namely five-halves law and independence of photoemission threshold on the nature of metal. Linear relationship is established between mean hydration range of electrons and their energy.

Photoemission method is used to study the double layer structure and kinetics of some electrochemical reactions on solid metals. A new method is suggested for determination of zero charge potential from intersection of photocurrentpotential curves obtained in solutions with variable electrolyte concentration. Effects of $\phi^{1}$-potential and specific adsorption on the total photoemission process in dilute solutions are analyzed.
\end{abstract}

*) Full text of the paper presented at the JAPAN-USSR Seminar on Electrochemistry in Tokyo will be published in Journal of Electroanalytical Chemistry and Interfacial Electrochemistry.

**) Institute of Electrochemistry, Academy of Sciences of the USSR, Moscow. 